\title{
Assessment of soil and source water characteristics of disused shrimp ponds in selected coastal states of India and their suitability for resuming aquaculture
}

\author{
R. SARASWATHY*, T. RAVISANKAR, P. RAVICHANDRAN, D. DEBORAL VIMALA, \\ M. JAYANTHI, M. MURALIDHAR, C. MANOHAR, M. VIJAY AND T. C. SANTHARUPAN \\ ICAR-Central Institute of Brackishwater Aquaculture, 75 Santhome High Road, R. A. Puram, Chennai - 600028 \\ Tamil Nadu, India \\ e-mail: saraswati@ciba.res.in
}

\begin{abstract}
The key objective of this study was to assess the suitability of soil and source water quality of abandoned shrimp farms in selected coastal states of India, for resuming aquaculture activities. Soil samples along with associated source water were collected from 60 disused shrimp ponds in different districts of Andhra Pradesh, Tamil Nadu, Odisha and Kerala and analysed for basic physico-chemical parameters. Results of the analysis indicated that the reason for disuse might be reduction in price/repeated occurrences of diseases and that the sampled farms are suitable for aquaculture use. Most of the soil in Andhra Pradesh and Tamil Nadu are suitable for aquaculture without any remediation. Few ponds in Jagatsingpur and Puri districts of Odisha and Kerala needs simple remediation measures like application of lime to increase the soil $\mathrm{pH}$. Source water in Tamil Nadu, Andhra Pradesh and Odisha (Harishpur Creek, Budhabalanga Creek and the coastal canal) fall under high saline areas and are suitable for culture of tiger shrimp Penaeus monodon, white shrimp Litopenaeus vannamei and finfishes like Asian seabass Lates calcarifer and mullets whereas, Kerala and northern parts of Chilka Lake of Odisha fall under low saline areas and are suitable for culture of white shrimp L. vannamei and pearlspot Etroplus suratensis.
\end{abstract}

Keywords: Disused ponds, Management practices, Shrimp, Soil and source water characteristics

The area under shrimp culture in India is significantly growing to cater to the increasing demand for aquaculture production. On the other hand, there are a larger number of aquaculture ponds in disuse in the country. Ponds that were used for aquaculture earlier, but discontinued due to various external reasons and remain unused are termed as disused ponds. This is a temporary phenomenon and the ponds can be put into use again. The total area of shrimp ponds in disuse as estimated by Ravisankar et al. (2014), is around 40000 ha in Andhra Pradesh, Odisha, Kerala and Tamil Nadu. Although there are a number of reasons for disuse of shrimp ponds, the declining environmental suitability resulting in increased incidence of diseases and ultimate failure of the crop are the major reasons (Chanratchakool et al., 1995). In India (Sammut and Mohan, 1996), Philippines and Taiwan (Ogburn and Ogburn, 1994) and Indonesia, the disuse is mainly due to disease related problems. Acid sulphate nature of soil is the problem for disuse in Vietnam (Tuan, 1996) and Cambodia (Sreng, 1996). In Sri Lanka, disused ponds are a result of improper site selection and poor water quality (Jayasinghe, 1995). To date, there are no published reports on the soil and water conditions of disused shrimp ponds in India. The present study analysed the physicochemical characteristics of disused shrimp pond soils and source waters in order to assess the feasibility for resuming aquaculture activities in these ponds and to suggest measures to bring these abandoned ponds back to productive use.

Disused shrimp farms were selected based on the results of questionnaire survey carried out under the project "Economics of shrimp ponds in disuse and participatory appraisal of productive use options and policy needs" funded by National Bank for Agriculture and Rural Development (Ravisankar et al., 2014). The area under disuse in Andhra Pradesh, Tamil Nadu, Kerala and Odisha were $7287 ; 2424 ; 654$ and 15,888 ha respectively. The farms under disuse for more than 2 - 4 years were selected for the study. However, in most of the disused shrimp farms in Tamil Nadu, culture was discontinued for more than 5 - 7 years. The districts and the location of sampling sites (village names) from where soil samples were collected from disused ponds are given in Table 1. Soil and water samples were analysed following standard methods.

In Andhra Pradesh, soil $\mathrm{pH}$ is alkaline in nature and the electrical conductivity (EC) recorded was than $5 \mathrm{dS} \mathrm{m}^{-1}$, which is suitable for shrimp farming. Calcium carbonate content of the soils from Krishna and Guntur districts were 4.02 and $2.37 \%$ respectively. Most of the 
Table 1. Sampling locations (villages) in coastal states of India

\begin{tabular}{|c|c|c|c|c|c|c|c|c|c|}
\hline \multirow{2}{*}{$\begin{array}{l}\text { State } \\
\text { District }\end{array}$} & \multicolumn{2}{|c|}{ Andhra Pradesh } & \multicolumn{2}{|c|}{ Tamil Nadu } & \multicolumn{3}{|c|}{ Odisha } & \multicolumn{2}{|c|}{ Kerala } \\
\hline & Krishna & Guntur & Nagapattinam & Thoothukudi & Jagatsingpur & Puri & Balasore & Alappuzha & Ernakulam \\
\hline \multirow[t]{4}{*}{ Locations } & $\begin{array}{l}\text { Koduru } \\
\text { (18 farms) }\end{array}$ & Thumalapallee & $\begin{array}{l}\text { Vedaranyam } \\
(2 \text { farms })\end{array}$ & $\begin{array}{l}\text { Ottapidaram } \\
(5 \text { farms })\end{array}$ & Basanta & Badbena & Kasafal & Vayalar & Chellanam \\
\hline & $\begin{array}{l}\text { Bandar } \\
\text { (7 farms) }\end{array}$ & $\begin{array}{l}\text { Nijampattinam } \\
\text { (2 farms) }\end{array}$ & & & Kushpur & Nuagada & Podikya & $\begin{array}{l}\text { Thurarvoor } \\
\text { (4 farms) }\end{array}$ & Kottuvally \\
\hline & $\begin{array}{l}\text { Kona } \\
\text { (2 farms) }\end{array}$ & & & & Sahada & Haridass & Parthampur & & $\begin{array}{l}\text { Kumbalanghi } \\
\text { (2 farms) }\end{array}$ \\
\hline & & & & & Gada & Kantapada & Grude Gudubhai & & Pallipuram \\
\hline
\end{tabular}

soils collected from disused ponds of Krishna District recorded organic carbon content near the minimum level of $0.5 \%$. In Guntur, organic carbon and available nitrogen content were lower than the optimum level of $0.5 \%$ and

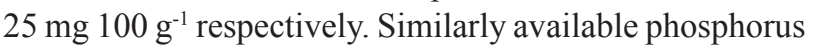
content was also lower than the optimum level of 4 - $6 \mathrm{mg} 100 \mathrm{~g}^{-1}$ of soil (Table 2). It may be due to non-utilisation of ponds over the years and the nutrient level can be brought to the required level by applying manures and fertilizers. Drying of pond and ploughing during pond preparation will help to increase mineralisation and in turn increase the availability of nutrients (Saraswathy et al., 2013). Most of the soils from Krishna and Guntur districts had sandy clay loam and sandy loam texture suitable for construction of bunds, which can help to reduce seepage loss and act as good reservoir of nutrients. Generally soils with 5 to $10 \%$ clay and a well graded particle size distribution are preferable for earth work construction (McCarthy, 1998) and more amenable to drying and tilling between crops (Boyd, 1995).

$\mathrm{pH}$ of water samples varied from 6.94 to 8.06 in Andhra Pradesh, which is in the optimum range for shrimp aquaculture. For most species, $\mathrm{pH}$ between 6.5 and 9 is ideal for growth. Below $\mathrm{pH} 6.5$, animal's ability to maintain salt balance is affected which results in slow growth (Lioyd, 1992) and reproduction ceases. $\mathrm{pH}$ problems associated with aquaculture are usually not due to source water but results from bio-giochemical processes and management practices followed during the culture period. Source water from Guntur District recorded $25 \mathrm{ppt}$ salinity and most of the creek water samples in Krishna District recorded salinity of more than 22 ppt except for water from Murugukalvai and Kona locations of Koduru Mandal (5 and 7 ppt respectively). Thungabhadra source water from Guntur District recorded comparatively higher alkalinity (247 ppm) while water from Krishna District had $174 \mathrm{ppm}$ (Table 3). The major reasons for disuse of shrimp farms in the Krishna District were the disease outbreaks coupled with high production cost. Source water falls under high saline areas and is suitable for culture of Penaeus monodon and Litopenaeus vannamei and finfishes like Asian seabass and grey mullet.

In Tamil Nadu, $\mathrm{pH}$ values of soil varied from 8 to 8.48 indicating the alkaline nature of soil. Electrical conductivity and calcium carbonate content were more than $4 \mathrm{dS} \mathrm{m}^{-1}$ and $5 \%$ respectively, indicating suitability for aquaculture. Organic carbon, available nitrogen and phosphorus content were less than required minimum value (Table 2). Organic manure can be applied to increase

Table 2. Soil quality of disused shrimp ponds in Andhra Pradesh and Tamil Nadu

\begin{tabular}{|c|c|c|c|c|}
\hline \multirow[b]{2}{*}{ Locations } & \multicolumn{2}{|c|}{ Andhra Pradesh } & \multicolumn{2}{|c|}{ Tamil Nadu } \\
\hline & $\begin{array}{l}\text { Krishna } \\
\text { (mean of } 27 \text { ponds) }\end{array}$ & $\begin{array}{l}\text { Guntur } \\
\text { (mean of } 3 \text { ponds) }\end{array}$ & $\begin{array}{l}\text { Nagapattinam } \\
\text { (mean of } 2 \text { ponds) }\end{array}$ & $\begin{array}{l}\text { Thoothukudi } \\
\text { (mean of } 5 \text { ponds) }\end{array}$ \\
\hline $\mathrm{pH}$ & 8.25 & 8.34 & 8.26 & 8.35 \\
\hline $\mathrm{EC}\left(\mathrm{dS} \mathrm{m}^{-1}\right)$ & 20.17 & 10.2 & 12.97 & 14.37 \\
\hline Organic carbon (\%) & 0.45 & 0.34 & 0.29 & 0.323 \\
\hline $\mathrm{CaCO}_{3}(\%)$ & 4.02 & 2.37 & 10.49 & 15.42 \\
\hline Available-N (mg $\left.100 \mathrm{~g}^{-1}\right)$ & 2.57 & 2.05 & 4.47 & 3.02 \\
\hline Total- N (mg $\left.100 \mathrm{~g}^{-1}\right)$ & 21.46 & 19.53 & 23.59 & 20.6 \\
\hline Available-P (mg $\left.100 \mathrm{~g}^{-1}\right)$ & 0.59 & 1.04 & 1.243 & 1.129 \\
\hline Total-P (mg $\left.100 \mathrm{~g}^{-1}\right)$ & 27.10 & 18.76 & 77.42 & 59.76 \\
\hline Texture & ${ }^{*} \mathrm{scl}, \mathrm{sl}$ & $\mathrm{sl}$ & $\mathrm{sl}, \mathrm{scl}$ & $\mathrm{sl}, \mathrm{l}, \mathrm{scl}, \mathrm{cl}$ \\
\hline
\end{tabular}

"scl: sandy clay loam, sl: sandy loam, cl: clay loam, l: loamy 
Table 3. Characteristics of source water of disused shrimp ponds in Andhra Pradesh and Tamil Nadu

\begin{tabular}{|c|c|c|c|c|c|c|c|c|c|}
\hline \multirow{3}{*}{$\begin{array}{l}\text { Districts } \\
\text { Locations }\end{array}$} & \multicolumn{7}{|c|}{ Andhra Pradesh } & \multicolumn{2}{|c|}{ Tamil Nadu } \\
\hline & \multicolumn{5}{|c|}{ Krishna } & \multicolumn{2}{|c|}{ Guntur } & \multirow{2}{*}{$\begin{array}{l}\text { Nagapattinam } \\
\text { Uppanar creek }\end{array}$} & \multirow{2}{*}{$\begin{array}{l}\text { Thoothukudi } \\
\text { Punnaikayal }\end{array}$} \\
\hline & Hamsa & Murugu & Rathnakudu & Kona & Leeja & Dunga (W) & Dunga (S) & & \\
\hline$\overline{\mathrm{pH}}$ & 7.86 & 7.52 & 7.52 & 8.06 & 7.68 & 6.94 & 7.16 & 7.77 & 7.01 \\
\hline Salinity (ppt) & 22 & 5 & 11 & 7 & 25 & 25 & 25 & 24 & 32 \\
\hline $\mathrm{TA}\left(\mathrm{ppm}\right.$ as $\left.\mathrm{CaCO}_{3}\right)$ & 177 & 208 & 212 & 137 & 137 & 267 & 227 & 433 & 456 \\
\hline Calcium (ppm) & 194 & 78 & 147 & 85 & 388 & 591 & 591 & 234 & 830 \\
\hline Magnesium (ppm) & 884 & 118 & 337 & 195 & 744 & 1290 & 1290 & 439 & 899 \\
\hline $\mathrm{TH}\left(\mathrm{ppm}\right.$ as $\left.\mathrm{CaCO}_{3}\right)$ & 3686 & 688 & 1775 & 1028 & 4074 & 6853 & 6853 & 2429 & 5851 \\
\hline Phosphate (ppm) & 0.0405 & 0.2879 & 0.0711 & 0.9250 & 0.0460 & 0.0582 & 0.0625 & 0.0807 & 0.2971 \\
\hline Nitrate-N (ppm) & 0.6085 & 0.6137 & 0.4644 & 1.3417 & 0.772 & 0.2984 & 0.354 & 0.1594 & 0.1931 \\
\hline
\end{tabular}

TA: Total alkalinity; TH: Total hardness

the organic carbon content of the soil. The nutrient level can be brought up to the required level by applying manures and fertilizers. Soil had sandy clay loam, clay loam and loamy texture, suitable for construction of bunds and reduced seepage losses which can act as good reservoir of nutrients.

Water collected from Uppanar Creek of Nagapattinam and Punnaikayal Creek in Thoothukudi recorded $\mathrm{pH}$ values of 7.77 and 7.01 respectively. Salinity was $24 \mathrm{ppt}$ in Uppanar Creek and 32 ppt in Punnaikayal Creek. Being high saline water sources, calcium and magnesium were more than the required limit for aquaculture; total alkalinity ranged from 433 to $456 \mathrm{ppm}$ as $\mathrm{CaCO}_{3}$ (Table 3) All the parameters were found in the optimum range for aquaculture. The major constraint which led to discontinuation of shrimp farming is the frequent crop failure due to diseases. Though Tamil Nadu farmers listed land lease policy of the state Government as the top constraint, the second one was disease. Based on water salinity, Tamil Nadu is suitable for culture of shrimp species $P$. monodon and L. vannamei and finfishes viz., Asian Seabass and grey mullet.
In Odisha, the average soil $\mathrm{pH}$ was on the lower side (5.8) in Jagatsinghpur and Puri districts whereas, in Balasore District, the soil $\mathrm{pH}$ was 7.85. $\mathrm{pH}$ can be improved by the application of agriculture lime $@ 6.9 \mathrm{t} \mathrm{ha}^{-1}$ before starting the culture (Boyd, 1981). In Jagatsingpur District, most of the soils were either sandy loam or loamy sand. In Puri and Balasore districts, the soil texture was sandy clay loam and silty clay loam, respectively (Table 4). In Balasore District, organic carbon content was less than the required minimum value. However it can be increased by the application of organic manure. Soils in all three districts of Odisha recorded $\mathrm{CaCO}_{3}$ values lower than the minimum level required for aquaculture. Application of lime has multiple benefits like increasing the soil $\mathrm{pH}, \mathrm{CaCO}_{3}$ content and reducing harmful substances like sulphides and acids. Nutrient level can be brought up to the required level by the application of fertilizers and manures.

$\mathrm{pH}$ values of the source water from Chilka Lake, Harishpur Creek, Budhabalanga Creek and Odisha coastal canal were 7.71, 6.89, 7.27 and 7.35 respectively. Salinity

Table 4. Soil quality of disused ponds in Odisha and Kerala

\begin{tabular}{|c|c|c|c|c|c|}
\hline \multirow[b]{2}{*}{ Locations } & \multicolumn{3}{|c|}{ Odisha } & \multicolumn{2}{|c|}{ Kerala } \\
\hline & $\begin{array}{l}\text { Jagatsingpur } \\
\text { (Mean of } 4 \text { places) }\end{array}$ & $\begin{array}{l}\text { Puri } \\
\text { (Mean of } 4 \text { places) }\end{array}$ & $\begin{array}{l}\text { Balasore } \\
\text { (Mean of } 5 \text { places) }\end{array}$ & Alappuzha & Ernakulam \\
\hline $\mathrm{pH}$ & 5.76 & 5.85 & 7.85 & 4.48 & 4.76 \\
\hline $\mathrm{EC}\left(\mathrm{dS} \mathrm{m} \mathrm{m}^{-1}\right)$ & 10.94 & 2.39 & 11.06 & 4.03 & 3.46 \\
\hline Organic carbon $(\%)$ & 0.6 & 0.86 & 0.18 & 1.43 & 1.4 \\
\hline $\mathrm{CaCO}_{3}(\%)$ & 2.1 & 1.96 & 1.31 & 1.55 & 1.65 \\
\hline Available-N (mg $\left.100 \mathrm{~g}^{-1}\right)$ & 2.52 & 2.94 & 3.45 & 3.4 & 4.36 \\
\hline Total-N (mg/100 g $\left.\mathrm{g}^{-1}\right)$ & 18.1 & 24.3 & 22.0 & 20.6 & 16.9 \\
\hline Available-P (mg $\left.100 \mathrm{~g}^{-1}\right)$ & 0.66 & 0.96 & 1.93 & 0.93 & 0.86 \\
\hline Total-P (mg $\left.100 \mathrm{~g} \mathrm{~g}^{-1}\right)$ & 21.7 & 28.3 & 44.7 & 20.3 & 27.1 \\
\hline Texture & ${ }^{*} \mathrm{sl}, \mathrm{ls}, \mathrm{scl}$ & $\mathrm{scl}$ & sicl & $\mathrm{sl}, \mathrm{s}$ & $\mathrm{sl}, \mathrm{s}$ \\
\hline
\end{tabular}

"sl: sandy loam, 1s: loamy sand, scl: sandy clay loam, sicl: silty clay loam, s: sandy 
of water from northern sector of Chilka Lake was $7 \mathrm{ppt}$, whereas Harishpur and Budhabalangs creeks recorded 25 and 31 ppt respectively. Coastal canal water recorded the highest salinity of $35 \mathrm{ppt}$. The total alkalinity values ranged between 137 to $188 \mathrm{ppm}$ as $\mathrm{CaCO}_{3}$ (Table 5), which is in the suitable range for use as source water for aquaculture. Nutrients like nitrate and phosphate helps in algal bloom development during culture. Nitrate was higher than the phosphate content in the source water collected and the lowest level of nutrient content was recorded in the water from Odisha. These nutrients can be supplemented during the culture period by feed management and application of plankton promoters. The major constraint for disuse is non-availability of disease free quality shrimp seed. Based on water salinity, Harishpur Creek, Budhabalanga Creek and the coastal canal of Odisha are suitable for culture of shrimp species P. monodon, L. vannamei and finfishes, Asian seabass and mullets whereas, Chilka Lake of Odisha is suitable for L. vannamei and Etroplus suratensis. loam texture. In this type of soil, nutrient holding capacity is low and seepage loss may be high. On the contrary, better growth and survival of penaeid shrimps have been reported on sandy substrates (Chien et al. 1989; Bray and Lawrence, 1993). The high sand and organic carbon content of the soil in disused ponds in Kerala are suitable for aquaculture.

In Kerala, $\mathrm{pH}$ of source waters (Kayamkulam and Vembanad backwater) ranged from 6.92 to 7 and the salinity was 5 ppt. Total alkalinity values ranged between 91 and $125 \mathrm{ppm}$ as $\mathrm{CaCO}_{3}$ (Table 5), which is in the suitable range for use as source water for aquaculture. Desirable range of $\geq 100$ or $150 \mathrm{ppm}$ was reported by Meade (1989) and Tucker and Robinson (1990). Calcium and magnesium values were lower than the minimum required value and can be increased by the application of lime and mineral mixtures during culture period. Nitrate was higher than the phosphate content in the source

Table 5. Source water characteristics of disused shrimp ponds in Odisha and Kerala

\begin{tabular}{|c|c|c|c|c|c|c|}
\hline \multirow[b]{2}{*}{ Parameters } & \multicolumn{4}{|c|}{ Odisha } & \multicolumn{2}{|c|}{ Kerala } \\
\hline & $\begin{array}{l}\text { Chilka Lake } \\
\text { Creek }\end{array}$ & $\begin{array}{l}\text { Goda Harishpur } \\
\text { Creek }\end{array}$ & $\begin{array}{l}\text { Coastal } \\
\text { canal }\end{array}$ & $\begin{array}{l}\text { Budhabalanga } \\
\text { Creek }\end{array}$ & $\begin{array}{l}\text { Kayamkulam } \\
\text { backwater }\end{array}$ & $\begin{array}{l}\text { Vembanad } \\
\text { backwater }\end{array}$ \\
\hline $\mathrm{pH}$ & 7.71 & 6.89 & 7.27 & 7.35 & 7 & 6.92 \\
\hline Salinity (ppt) & 7 & 25 & 35 & 31 & 5 & 5 \\
\hline $\mathrm{TA}\left(\mathrm{ppm}\right.$ as $\left.\mathrm{CaCO}_{3}\right)$ & 137 & 171 & 173 & 188 & 125 & 91 \\
\hline Calcium (ppm) & 133 & 259 & 218 & 349 & 80 & 86 \\
\hline Magnesium (ppm) & 360 & 1088 & 1099 & 1125 & 109 & 130 \\
\hline $\mathrm{TH}\left(\mathrm{ppm}\right.$ as $\left.\mathrm{CaCO}_{3}\right)$ & 1836 & 5184 & 5123 & 5559 & 653 & 756 \\
\hline Phosphate (ppm) & 0.034 & 0.0703 & 0.079 & 0.1015 & 0.1803 & 0.1289 \\
\hline Nitrate-N (ppm) & 0.0323 & 0.3012 & 0.0255 & 0.0046 & 1.8749 & 2.6767 \\
\hline
\end{tabular}

TA: Total alkalinity; TH: Total hardness

In Kerala, soil samples collected from both Alappuzha and Ernakulam districts revealed acidic nature with the average $\mathrm{pH}$ values of 4.5 and 4.8 , respectively. $\mathrm{pH}$ can be improved by the application of 12.5 to $13.9 \mathrm{t} \mathrm{ha}^{-1}$ lime before starting the culture (Boyd, 1981). In most of the soils, EC values were lower than $4 \mathrm{dS} \mathrm{m}^{-1}$ and organic carbon content was around $1.4 \%$ (Table 4). Higher value of organic carbon content is due to wetness of soil throughout the year. The organic carbon content can be reduced by properly drying the farm which could help to increase the decomposition rate. All the soils recorded $\mathrm{CaCO}_{3}$ values lower than the minimum level required for aquaculture. Application of lime has multiple benefits like increasing the soil $\mathrm{pH}, \mathrm{CaCO}_{3}$ content and reducing harmful substances like sulphides and acids. Availability of nutrients (nitrogen and phosphorus) may be increased by drying of pond and ploughing during pond preparation. In Kerala, most of the soils had loamy sand and sandy water. Nutrient levels can be maintained at optimum levels during the culture period by feed management and application of plankton promoters. Similar to Odisha, the major constraint for disuse is non-availability of disease free quality shrimp seed. Based on water salinity of source water it appears that Kerala is suitable for culture of L. vannamei and E. surantensis.

In all the four states studied, the disuse of shrimp farms occurred not due to changed pond environmental factors like soil and source water, but due to the factors like decrease in market price for shrimp and repeated occurrence of disease. Based on the salinity of source water, appropriate species need to be selected and cultured. For example, Tamil Nadu, Andhra Pradesh, Harishpur Creek, Budhabalanga Creek and the coastal canal of Odisha are suitable for culture of shrimp species P. monodon and L. vannamei and finfishes, seabass and mullet whereas, Kerala and Chilka Lake of Odisha are 
suitable for L.vannamei and E. suratensis Popularisation of cost effective feed formulations, biosecurity protocols and promotion of specific pathogen free (SPF) seed stocks will help shrimp farming to become more resilient. Effect of international shrimp price crashes could be dampened by developing a domestic market network. The erstwhile aquaculture farmers could be motivated to restart aquaculture in the disused shrimp ponds by providing technical and financial support for adopting better management practices.

\section{Acknowledgements}

The authors are thankful to the National Bank for Agriculture and Rural Development (NABARD) for providing financial support to the study.

\section{References}

Boyd, C. E. 1995. Bottom soils, sediment and pond aquaculture. Chapman and Hall, New York, USA.

Boyd, C. E. 1981. Water quality in warm water fish ponds. Auburn University, Alabama. Craftmaster printers Inc., Opelika, Alabama, 359 pp.

Bray, W. A. and Lawrence, A. L. 1993. The effect of four substrates on growth and survival of Penaeus vannamei at two salinities. Ciencias Marinas, 19: 229-534.

Chanratchakool, P., Turnbull, J., Funge-Smith, S. and Limsuwan, C. 1995. Health management in shrimp ponds, $2^{\text {nd }}$ edn. Aquatic Animal Health Research Institute, Department of Fisheries, Kasetsart University Campus, Bangkok, Thailand, $111 \mathrm{pp}$.

Chien, Y. H., Lai, H. T. and Chang, S. K. 1989. The effect of steel making waste slags as substrate on shrimp Penaeus monodon reared in aquaria. Asian Fish. Sci., 2: 147-161.

Jayasinghe, J. M. P. K. 1995. Sri Lanka in FAO/NACA 1995. Regional study and workshop on the environmental assessment and management of aquaculture development (TCP/RAS/2253). NACA environment and aquaculture development Series No. 1. Network of Aquaculture Centres in Asia-Pacific, Bangkok, Thailand, p. 357-376.

Lioyd, R. 1992. Pollution and freshwater fish. West Byfleet, Fishing News (Books) Ltd., 195 pp.

McCarthy, D. F. 1998. Essentials of soil mechanics and foundations: basic geotechnics, $5^{\text {th }}$ edn. Prentice Hall. Upper Saddle River, New Jersey, USA, 730 pp.
Meade, J. W. 1989. Aquaculture management. Van Nostrand Reinhold, New York, 175 pp.

Ogburn, D. M. and Ogburn, N. J. 1994. Intensive pond culture trials of the green grouper (Epinephelus malabaricus Bloch \& Schneider) in the Philippines. In: Chou, L. M. (Ed.), Prceeding of the third Asian Fisheries Forum. Asian Fisheries Society, Manila, Philippines, p. 74-77.

Ravisankar, T., Ravichandran, P., Deboral Vimala, D., Jayanthi, M., Saraswathy, R., Santha Ruban, T. C. and Vijay, M. 2014. Economics of shrimp ponds in disuse and participatory appraisal of productive use options and policy needs. Project final report, National Bank for Agriculture and Rural Development (NABARD), 207 pp.

Sammut, J. and Mohan, C. V. 1996. Processes and impacts of estuarine acidification: the Richmond River, NSW and Karnataka, India. In: Acid sulphate soils-causes, management, effects, rehabilitation, prevention? Issues for Eastern Australia and Asia. 29 July 1996, The Earth Science Foundation, Department of Geology and Geophysics, The University of Sydney, 4 pp.

Saraswathy, R., Muralidhar, M., Kailasam, M., Ravichandran, P., Gupta, B.P., Krishnani, K. K., Ponniah,A. G., Sundaray, J. K., Panigrahi, A. and Nagavel, A. 2013. Effect of stocking density on soil, water quality and nitrogen budget in Penaeus monodon (Fabricius, 1798) culture under zero water exchange system. Aquac. Res., 44: 1578-1588.

Sreng, L. 1996. Mangroves in Kampot Province, Cambodia. In: Proceedings of the ECOTONE V Regional Seminar: Community participation in conservation, sustainable use and rehabilitation of mangroves in South-east Asia, Ho Chi Minh City, Vietnam, 8-12 January, 1996. Mangrove Ecosystem Research Centre (MERC), Vietnam National University, Vietnam, 13 pp.

Tuan, M. S. 1996. Building up the strategy for mangrove management in Vietnam. In: Proceedings of the ECOTONE V Regional Seminar: Community participation in conservation, sustainable use and rehabilitation of mangroves in southeast Asia, Ho Chi Minh City, Vietnam, 8-12 January 1996. Mangrove Ecosystem Research Centre (MERC), Vietnam National University, Vietnam, 35 pp.

Tucker, C. S. and Robinson, E. H. 1990. Channel catfish farming handbook. Van Nostrand Reinhold, New York, 454 pp.

Date of Receipt $\quad$ : 01.01 .2015

Date of Acceptance : $\quad 03.02 .2016$ 